\title{
MAXIMAL CARDIORESPIRATORY RESPONSES OF MALES AND FEMALES TO BICYCLE AND TREADMILL ERGOMETRY
}

\author{
J. L. MAYHEW, M.S. ${ }^{1}$ and B. A. CLARK, Ph.D. ${ }^{2}$ \\ ${ }^{1}$ Department of Physical Education University of Illinois, Champaign, Illinois, USA \\ ${ }^{2}$ Department of Physical Education, University of Missouri - St. Louis, Missouri, USA
}

\section{Introduction}

The emergence of females in all realms of activity has prompted more investigation of their functional capabilities. At present there is a dearth of comparative information in the physiological realm which has lead to diverse conjecture regarding the ability of females to compete with and against males. Generally, females do not respond differently than males to submaximal work (14, 18). At maximum performance levels, however, males are significantly superior when parameters are considered in absolute terms $(10,13,15,18)$. When parameters are considered relative to body size, as, per kilogram body weight (BW) or lean body mass (LBM), the differences are reduced but not totally removed $(10$, 13).

The purpose of this study was to compare the physiological response of comparable groups of males and females to maximal exercise stress. More specifically, this research evaluated and compared (1) the cardiorespiratory response of each sex relative to body composition on a bicyle ergometer and motor-driven treadmill, and (2) the difference in the reaction of both sexes to the two forms of ergometry.

\section{Methodology}

Subjects. The subjects were 13 male and 11 female volunteers whose activity levels ranged from sedentary to trained in both sexes. There was approximately the same proportion of trained individuals in each group as determined by subject questioning prior to experimentation. Testing order for administration of the two forms of ergometry was determined randomly. Group physical characteristics are shown in Table I.

Bicycle ergometer test. Each subject reported to the laboratory at least 2 hours postabsorptive and without strenuous exercise for 12 hours preceding the test. A 5 -minute warmup, $720 \mathrm{kpm} / \mathrm{min}$ for males and 360 $\mathrm{kpm} / \mathrm{min}$ for females, was given. Following a 5-minute rest each subject began pedalling at a load which would exhaust the individual in 5-10 minutes (based on subjective estimates of their physical condition). Subjects ceased exercising by voluntary termination or when the pedalling rate fell below $50 \mathrm{rpm}$.

One-minute aliquots of expired gas were collected throughout the test on the apparatus previously described (17). Gas samples were analyzed using electronic analyzers (Beckman E-2 oxygen and MSA Lira 300 Carbon dioxide analyzers) routinely calibrated with standard reference gases previously analyzed on a Lloyd-Haldane chemical apparatus. Heart rate was recorded during the last 15 seconds of every minute of exercise by telemetered electrocardiography (Narco Bio-System).

\section{TABLE I}

\section{Group Physical Characteristics}

$\begin{array}{llll}\text { Variable } & \begin{array}{l}\text { Males }(n=13) \\ \text { Mean SD }\end{array} & \text { Females }(n=11) & \% \text { Diff. } \\ & & & \frac{M-F}{M} \times 100\end{array}$

$\begin{array}{lccclr}\text { Age }(\mathrm{yrs}) & 26.37 & 4.97 & 23.98 & 3.95 & 9.1 \\ \text { Height }(\mathrm{cm}) & 179.1 & 7.3 & 163.0 & 5.1 & 9.0 \\ \text { Weight }(\mathrm{kg}) & 77.64 & 18.10 & 57.18 & 7.38 & 26.4 \\ \text { BSA }\left(\mathrm{m}^{2}\right) & 1.90 & 0.23 & 1.59 & 0.11 & 16.3 \\ \text { LBM }^{*}(\mathrm{~kg}) & 67.91 & 14.26 & 44.69 & 4.51 & 34.2 \\ \text { BCM }^{*}(\mathrm{~kg}) & 38.52 & 8.09 & 23.88 & 2.31 & 38.0 \\ \text { \%Fat } & 13.3 & 5.5 & 21.8 & 9.9 & 63.9\end{array}$

* Calculated from total body potassium.

Treadmill test. Each subject reported to the laboratory in a rested postabsorptive state as in the bicycle ergometer test. Males warmed up with a 5 -minute run at $11.3 \mathrm{~km} / \mathrm{hr}(0 \%$ grade), while females used a 5-minute walk at $5.6 \mathrm{~km} / \mathrm{hr}(0 \%$ grade), each followed by a 5-minute rest. The maximal stress test for males followed the protocol of Costill and Fox (4): 4 minutes at $0 \%$ grade followed by an initial increment to $4 \%$ elevation, with $2 \%$ increments every 2 minutes thereafter until voluntary termination. Female subjects followed the protocol of Costill and others $(5): 2$ minutes at $0 \%$ grade followed by $2.5 \%$ grade increments every 2 minutes until exhaustion. In both cases the speed of the treadmill for each subject was subjectively chosen on the basis of physical condition to reach termination in 5-10 minutes. Speeds ranged from 12.9 to $17.7 \mathrm{~km} / \mathrm{hr}$ for males and 8.0 to $11.3 \mathrm{~km} / \mathrm{hr}$ for females. One-minute heart rates were taken and gas aliquots collected and analyzed as described previously.

Body composition assessment. Body composition was evaluated by whole-body potassium counting using a $4 \pi$ 
liquid scintillation counter (23). Each subject was counted for 2 consecutive 4-minute periods with 4-minute background counts taken before and after the subject count. Efficiency of the counter was determined at each test session by counting a phantom of known ${ }^{40} \mathrm{~K}$ activity. Subjects were counted on 2 separate occasions within a time period of 5 to 9 days. Total body potassium (TBK), lean body mass (LBM), fat weight (FW), and percent fat (\%fat) were calculated at each occasion (3) with the mean representing the subject. The potassium constant used for males was 2.66 g K/kg LBM (8) and for females was $2.50 \mathrm{~g} \mathrm{~K} / \mathrm{kg} \mathrm{LBM}$ (9). Body cell mass (BCM) was calculated according to Moore and others (20).

Subcutaneous skinfolds were taken on each subject using Harpenden callipers at the following sites: triceps, subscapular, suprailiac, anterior thigh, and posterior calf.
Site locations and measurement methods were those of Wilmore and Behnke $(25,26)$.

Leg volume was measured by water displacement. Each measure was accomplished by submerging the right leg to the gluteal furrow.

\section{Results}

Maximal cardiorespiratory parameters are shown in Table II. In the case of both bicycle and treadmill, neither maximal heart rates nor breathing rates were significantly different between the sexes while maximal oxygen intake $\left(\mathrm{VO}_{2} \max \right)$, pulmonary ventilation $\left(\mathrm{V}_{E}\right)$, and $\mathrm{O}_{2}$ pulse were significantly different $(p<.001)$. When $\mathrm{VO}_{2}$ max was assessed in terms of body composition, only the treadmill value expressed in terms of BCM was not significantly different (Table II).

TABLE \|

Maximal Cardiorespiratory Parameters for Males $(n=13)$ and Females $(n=11)$

Variable

\section{Bicycle Ergometer}

$\mathrm{VO}_{2} \max (1 / \mathrm{min})$

$\mathrm{VO}_{2} \max (\mathrm{ml} / \mathrm{kg} \mathrm{BW} / \mathrm{min})$

$\mathrm{VO}_{2} \max (\mathrm{ml} / \mathrm{kg} \mathrm{LBM} / \mathrm{min})$

$\mathrm{VO}_{2} \max (\mathrm{ml} / \mathrm{kg} \mathrm{BCM} / \mathrm{min})$

$V_{E}(1 / \mathrm{min}$ BTPS)

Breathing rate

(breaths/min)

Maximal Heart Rate (bpm)

$\mathrm{O}_{2}$ Pulse (ml/beat)

\section{Treadmill}

$\mathrm{VO}_{2} \max (1 / \mathrm{min})$

$\mathrm{VO}_{2} \max (\mathrm{ml} / \mathrm{kg} \mathrm{BW} / \mathrm{min})$

$\mathrm{VO}_{2} \max (\mathrm{ml} / \mathrm{kg} \mathrm{LBM} / \mathrm{min})$

$\mathrm{VO}_{2} \max (\mathrm{ml} / \mathrm{kg} \mathrm{BCM} / \mathrm{min})$

$\dot{V}_{E}(1 / \min B T P S)$

Breathing rate

(breaths/min)

Maximal Heart Rate (bpm)

$\mathrm{O}_{2}$ Pulse (ml/beat)

${ }^{*} \mathrm{t}=2.07$ significant at .05 level
Males

Mean

SD

Females

Mean

SD

Diff.

$(M-F)$

$\%$ Diff.
$\frac{M-F}{M} \times 100$

t ratio

$\begin{array}{rr}4.09 & 0.53 \\ 54.1 & 8.8 \\ 61.5 & 8.4 \\ 108.4 & 14.8 \\ 156.8 & 32.6 \\ & \\ 55.2 & 9.0 \\ 178.2 & 12.2 \\ 23.1 & 3.9\end{array}$

2.18
38.8
49.2
92.0
89.3

0.43

10.2

10.5

19.7

11.1

52.9

184.9

11.8

7.5
10.4
2.0

1.91

15.3

12.3

16.4

67.5

2.3

$-6.7$

11.3

46.7

39.4

25.0

17.8

43.0

$9.57^{*}$

$3.95^{*}$

$3.19^{*}$

$2.33^{*}$

$6.53^{*}$

4.2

0.67

$-3.8$

48.9

$-1.43$

$8.69^{*}$

$\begin{array}{rrrrccc}4.46 & 0.51 & 2.46 & 0.38 & 2.00 & 44.8 & 10.73^{*} \\ 59.1 & 11.3 & 43.5 & 8.1 & 15.6 & 35.9 & 4.55^{*} \\ 67.4 & 11.0 & 55.4 & 8.9 & 12.0 & 21.7 & 4^{*} \\ 118.9 & 19.3 & 103.7 & 16.6 & 15.2 & 14.7 & 2.05 \\ 154.1 & 29.3 & 89.9 & 8.2 & 64.2 & 41.7 & 4.56^{*} \\ & & & & & & \\ 54.5 & 9.0 & 53.9 & 9.1 & 0.6 & 1.1 & 0.30 \\ 186.5 & 11.8 & 189.7 & 9.8 & -3.2 & -1.7 & 0.38 \\ 23.8 & 2.8 & 13.0 & 1.9 & 10.8 & 45.4 & 10.85^{*}\end{array}$




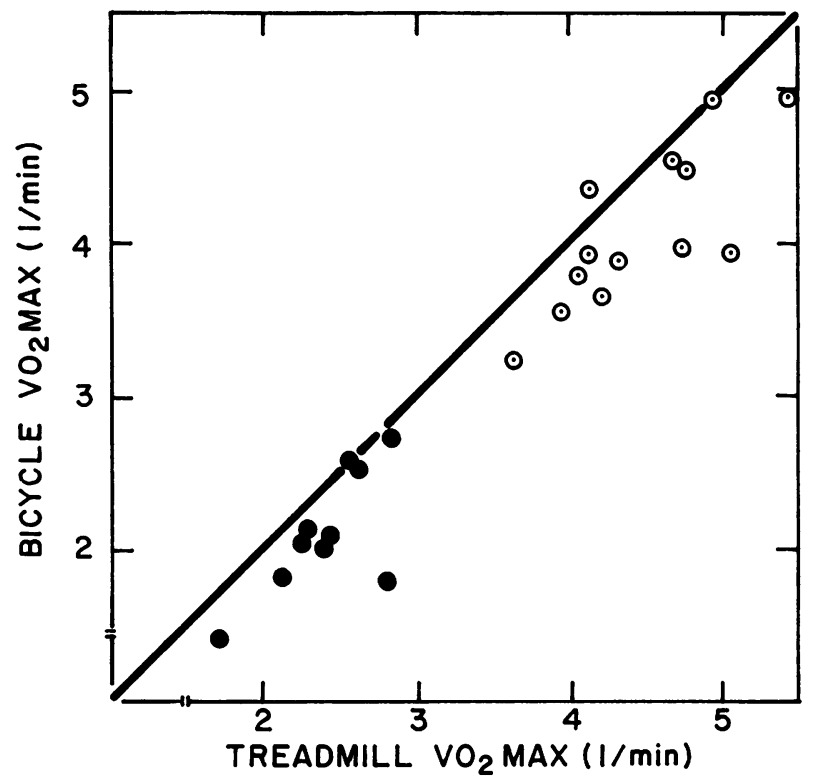

The difference between bicycle and treadmill $\mathrm{VO}_{2} \max (1 / \mathrm{min})$ for females was comparable to that of males (males $=8.3 \pm 7.1 \%$; females $=12.8 \pm 10.1 \%$ ) as shown in Figure 1. In both cases the difference between bicycle and treadmill $\mathrm{VO}_{2}$ max were significant $(p<.05)$ whether expressed in $1 / \mathrm{min}$ or in terms of body composition $(\mathrm{ml} / \mathrm{kg} \mathrm{BW} / \mathrm{min} . \mathrm{ml} / \mathrm{kg} \mathrm{LBM} / \mathrm{min}$ and $\mathrm{ml} / \mathrm{kg}$ $\mathrm{BCM} / \mathrm{min}$ ). Both males and females exhibited a significantly higher maximal heart rate on the treadmill than on the bicycle. The higher $\mathrm{VO}_{2} \max$ and the slightly higher HR of the females combined to yield a significantly higher $\mathrm{O}_{2}$ pulse during treadmill exercise. In males the smaller increase in $\mathrm{VO}_{2}$ max and the greater increase in $\mathrm{HR}$ produced an insignificantly higher $\mathrm{O}_{2}$ pulse during treadmill stress. Neither maximum breathing rate nor $V_{E}$ were significantly different between ergometers for both sexes.

Figure 1. Comparison of $\dot{\mathrm{V}}_{2} \max (1 / \mathrm{min})$ on bicycle and treadmill for males $(n=13, O)$ and females $(n=11,0)$.

Relationships of Anthropometric and Maximal Oxygen Intake Measultes

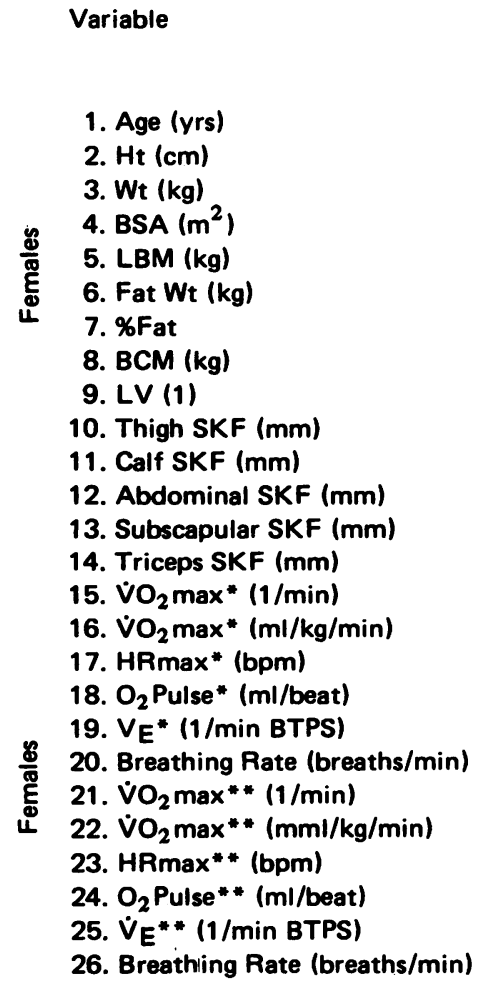
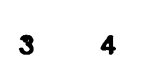

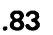

.78
.98

.86

.97

.86

.74

.74

1.00 .98

.75

"Measured on the bicycle ergometep 


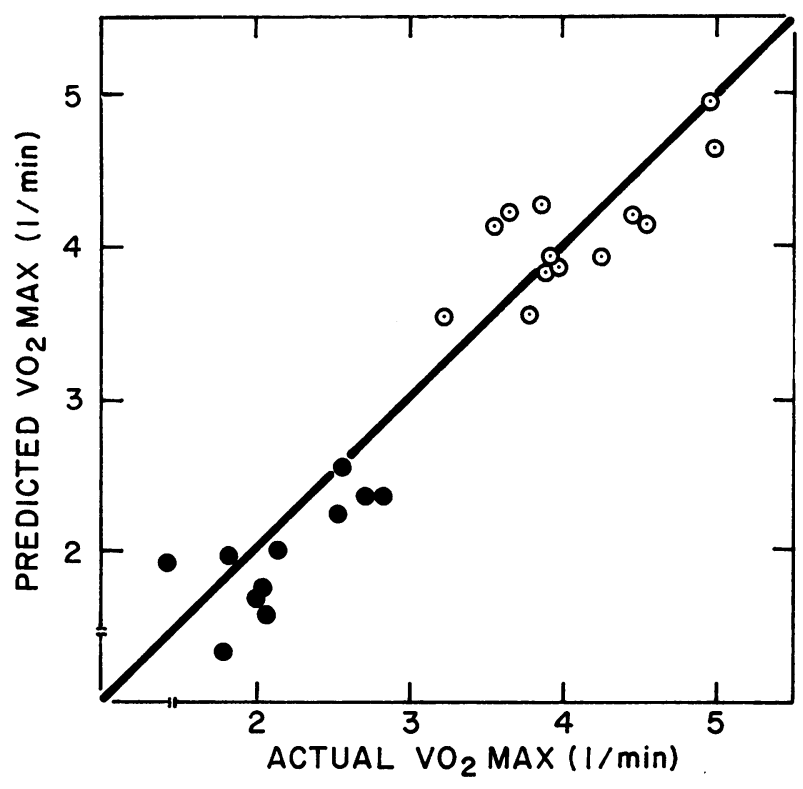

A greater number of anthropometric parameters were associated with maximal cardiorespiratory variables for males than for females (Table III). For males the only maximal cardiorespiratory parameter produced during bicycle exercise that was significantly related to the corresponding parameter elicited during treadmill stress was breathing rate $(r=.69)$. In females, however, $\mathrm{VO}_{2} \max (1 / \mathrm{min}$ and $\mathrm{ml} / \mathrm{kg} \mathrm{BW} / \mathrm{min}), \mathrm{HR}$, and $\mathrm{O}_{2}$ pulse were significantly related between the instruments.

It should be noted that absolute leg volume was significantly related to $\mathrm{VO}_{2} \max (1 / \mathrm{min})$ measured on the bicycle in males but not in females. When limb adipose content was accounted for through multiple repression analysis, the multiple R's for both sexes were identical (Figure 2). The equations for each sex were as follows:

Figure 2. Comparison of actual $\dot{\mathrm{V}} \mathrm{O}_{2} \max (1 / \mathrm{min})$ to value predicted from LV corrected for subcutaneous adipose tissue in males $(n=13, O)$ and females $(n=11$, O).

III

$n$ Males $(n=13)$ and Females $(n=11)$ Significant at the .01 Level

**Measured on the treadmill

\begin{tabular}{|c|c|c|c|c|c|c|c|c|c|c|c|c|c|}
\hline & \multicolumn{9}{|c|}{ Males } & \multicolumn{4}{|r|}{ Variable } \\
\hline 14 & 15 & 16 & 17 & 18 & 19 & 20 & 21 & 22 & 23 & 24 & 25 & 26 & \\
\hline & & & & & & & & & & & & & 1. Age (yrs) \\
\hline & & -.77 & & & .68 & & & -.74 & & & & & 2. $\mathrm{Ht}(\mathrm{cm})$ \\
\hline .89 & .69 & -.79 & & .70 & .70 & & & -.80 & & & & & 3. Wt (kg) \\
\hline .89 & .74 & -.73 & & .79 & & & .61 & -.72 & & & & & 4. $B S A\left(m^{2}\right)$ \\
\hline .79 & .78 & -.69 & & .80 & & & & -.70 & & .71 & .77 & & 5. LBM (kg) \\
\hline .82 & & -.77 & & & & & & -.72 & & & & & 6. Fat $W_{t}(\mathrm{~kg})$ \\
\hline .75 & & & & & & & & & & & & & 7. \%Fat \\
\hline .79 & .78 & -.69 & & .80 & .78 & & .64 & -.70 & & .71 & .77 & & 8. BCM (kg) \\
\hline .88 & .71 & -.75 & & .70 & .70 & & & -.71 & & & .67 & & 9. $L V(1)$ \\
\hline .87 & & & & & & & & & & & & & 10. Thigh SKF $(\mathrm{mm})$ \\
\hline .85 & & & & & & & & & & & & & 11. Calf SKF (mm) \\
\hline .76 & & -.73 & & & & & & & & & & & 12. Abdominal SKF (mm) \\
\hline .70 & & & & & & & & & & & & & 13. Subscapular SKF $(\mathrm{mm})$ \\
\hline .77 & & & & .92 & .76 & & .79 & & & .76 & .79 & .77 & 14. Triceps SKF (mm) \\
\hline & & & & & & & & .85 & & & & & 15. $\dot{\mathrm{VO}}_{2} \max *(1 / \mathrm{min})$ \\
\hline & .90 & & & -.69 & & & & .79 & -.63 & & & & 16. $\dot{V} \mathrm{O}_{2} \max { }^{*}(\mathrm{ml} / \mathrm{kg} / \mathrm{min})$ \\
\hline & & & & & .69 & & .77 & & & .84 & .69 & & 17. HRmax * (bpm) \\
\hline & .96 & .83 & & & & & & & & & .74 & & $\begin{array}{l}\text { 18. } O_{2} \text { Pulse* (ml/beat) } \\
\text { 19. } V_{E^{*}}(1 / \mathrm{min} \text { BTPS })\end{array}$ \\
\hline & & & & & & & & & & .83 & .80 & .66 & 20. Breathing Rate (breaths/min) \\
\hline & .78 & & & .83 & & & & & & & & & 21. $\dot{\mathrm{V}} \mathrm{O}_{2} \max * *(1 / \mathrm{min})$ \\
\hline & .90 & .95 & & .86 & & & & & & & & & 22. $\dot{\mathrm{VO}_{2}} \max * *(\mathrm{mml} / \mathrm{kg} / \mathrm{min})$ \\
\hline & & & .91 & & & & & & & & & & 23. HRmax** (bpm) \\
\hline & & & & .78 & & & .95 & & & & .72 & .84 & $\begin{array}{l}\text { 24. } O_{2} \text { Pulse** (ml/beat) } \\
\text { 25. } \dot{V}_{E}^{* *}(i / m i n ~ B T P S)\end{array}$ \\
\hline & & & & & & & & & & & .74 & & 26. Breathing Rate (breaths $/ \mathrm{min}$ ) \\
\hline
\end{tabular}


Males

$\mathrm{VO}_{2} \max (1 / \mathrm{min})=2.947+0.149 \mathrm{LV}(1)-0.0322$ thigh SKF $(\mathrm{mm})-0.0011$ calf SKF $(\mathrm{mm})$

$R=.75 \mathrm{SEE}=0.4001 / \mathrm{min}$

Females

$$
\begin{aligned}
& \mathrm{VO}_{2} \max (1 / \mathrm{min})=3.062+0.0249 \mathrm{LV}(1)-0.0585 \\
& \text { thigh SKF }(\mathrm{mm})-0.0099 \text { calf SKF }(\mathrm{mm}) \\
& \mathrm{R}=.75 \mathrm{SEE}=0.3451 / \mathrm{min}
\end{aligned}
$$

\section{Discussion}

The difference in $\mathrm{VO}_{2} \max (\mathrm{ml} / \mathrm{kg} / \mathrm{min})$ between the sexes found in this study was slightly greater than previous investigations (Table IV). The difference may have been spuriously affected by the relatively small number of subjects studied and their diverse fitness levels. When $\mathrm{VO}_{2} \max$ was considered relative to $\mathrm{BCM}$, the difference between the sexes was reduced to a value comparable to that found by MacNab and others (13) who considered $\mathrm{VO}_{2}$ max in terms of LBM determined densitometrically. Those authors explained the difference between the sexes $(\sim 14 \%)$ as being due to differences in haemoglobin content, although they did not actually measure that parameter. While it seems inviting to say that the remaining difference in $\mathrm{VO}_{2}$ max between the sexes, when LBM is accounted for, is due to the lower haemoglobin content of the females' blood, $(16,24)$, this may be an oversimplification. Nagle (21) stated that the difference between the sexes was due largely to the smaller organs (lungs, heart, and skeletal muscles) of the female. It may be the interaction of several physiological parameters that results in a lower $\mathrm{VO}_{2} \mathrm{max} / \mathrm{kg}$ ratio in females. Further research is necessary before definitive statements can be made.

\section{TABLE IV}

\begin{tabular}{|c|c|c|c|c|c|c|}
\hline \multirow[b]{2}{*}{ Study } & \multicolumn{3}{|c|}{ Bicycle $\dot{\mathrm{V}} \mathrm{O}_{2}$ max. } & \multicolumn{3}{|c|}{ Treadmill $\dot{\mathrm{V}} \mathrm{O}_{2}$ max. } \\
\hline & Male & Female & \%Diff. & Male & Female & \%Diff \\
\hline $\begin{array}{l}\text { Metheny \& } \\
\text { others (18) }\end{array}$ & & & & 51.3 & 40.9 & 25.4 \\
\hline $\begin{array}{l}\text { Hermanson A } \\
\text { \& Anderson S } \\
(10)\end{array}$ & $\begin{array}{l}71 \\
44\end{array}$ & $\begin{array}{l}55 \\
38\end{array}$ & $\begin{array}{l}29.1 \\
15.8\end{array}$ & & & \\
\hline $\begin{array}{l}\text { MacNab \& } \\
\text { others (13) }\end{array}$ & 46.5 & 35.7 & 30.2 & 51.7 & 39.1 & 32.2 \\
\hline $\begin{array}{l}\text { Present } \\
\text { Study }\end{array}$ & 54.1 & 38.8 & 39.4 & 59.1 & 43.5 & 35.9 \\
\hline
\end{tabular}

Difference in $\mathrm{VO}_{2} \max (\mathrm{ml} / \mathrm{kg} / \mathrm{min})$ for Males and Females with Bicycle and Treadmill Ergometry
The difference in $\mathrm{VO}_{2} \max (1 / \mathrm{min})$ for males between bicycle and treadmill exercise $(8.3 \%)$ was similar to the mean value of 13 studies reported in the literature (mean $=9.2 \pm 4.4 \%$ ). The only two studies reporting differences between $\mathrm{VO}_{2}$ max on bicycle and treadmill for females showed $4.5 \%$ (1) and $9.4 \%$ (13) greater aerobic capacities during maximal treadmill stress. The difference found in this study $(12.8 \%)$ was only slightly greater. The hypothesis that uphill treadmill running involves a greater muscle mass and therefore elicits a greater $\mathrm{VO}_{2} \max$ than bicycling (19) appears to have been substantiated by Secher and others (22), who reported a $6 \%$ higher $\mathrm{VO}_{2}$ max during arm + leg work than during leg work alone. Furthermore, arm + leg work did not result in a higher $\mathrm{VO}_{2}$ max than uphill treadmill running.

The greater maximal heart rate shown in treadmill exercise probably resulted in a greater cardiac output which coincided with earlier observations $(11,19)$. If the assumption is made that $\mathrm{O}_{2}$ pulse is a relative measure of stroke volume (2), the significantly higher $\mathrm{O}_{2}$ pulse for females during treadmill exercise might indicate an increase in stroke volume. An increased cardiac output in females, therefore, would have been produced by increases in both heart rate and stroke volume. However, since $\mathrm{O}_{2}$ pulse was not significantly increased in males exercising on the treadmill, the increase in cardiac output would have resulted principally from an increase in heart rate. Because $\mathrm{O}_{2}$ pulse must also involve, to some degree, the arteriovenous oxygen difference, and since the reaction of the a-v $\mathrm{O}_{2}$ difference during bicycle and treadmill exercise remains controversial $(7,19)$, further definitive research needs to be undertaken in this area.

The low correlation between leg volume and $\mathrm{VO}_{2}$ max $(1 / \mathrm{min})$ in females appeared to be due to the influence of adipose deposits in the lower limbs. When leg volume was "corrected" to lean leg volume by accounting for thigh and calf skinfold thicknesses, the leg volume $/ \mathrm{VO}_{2}$ max relationship was significant $(p<.01)$ in both sexes. The argument (6) that the major factors determining $\mathrm{VO}_{2}$ max during bicycle ergometry were the size and composition of the lower limbs has been challenged (12). When body weight was partialled out of the leg volume $/ \mathrm{VO}_{2}$ max relationship, the association was drastically reduced as shown elsewhere (12), and leg dimensions offered no greater advantage than body weight as a general reference standard for $\mathrm{VO}_{2} \max$. However, the higher correlation and lower standard error of estimate for the regression of $\mathrm{VO}_{2}$ max on leg volume, especially when the latter is corrected for adipose tissue, offers great promise for the prediction of $\mathrm{VO}_{2} \max$ from anthropometric measurements.

In conclusion, even with the limited sample observed here, males appear to differ in aerobic capacity from 
females no matter what the frame of reference. While the difference may be small when assessed in terms of LBM, both sexes must carry the entire body weight when participating in physicai activity. To this end the greater relative fat content of females is certainly a hinderance.

\section{REFERENCES}

1. ASTRAND, P. -O. Experimental studies of physical working capacity in relation to sex and age. Copenhagen: Munksgaard, 1952.

2. ÅSTRAND, P. -O.; RODAHL, K. Textbook of work physiology. New York: McGraw-Hill, 1970.

3. BOILEAU, R. A.; MASSEY, B. H.; MISNER, J. E. “Body composition changes in adult men during selected weight training and jogging programs." Res.Quart., 44: 158-168, 1973.

4. COSTILL, D. L.; FOX, E. L. “Energetics of marathon running." Med.Sci.Sports, 1: 81-86, 1969.

5. COSTILL, D. L.; THOMPSON, H.; ROBERTS, E. "Fractional utilization of the aerobic capacity during distance running." Med.Sci.Sports, 5: 248-252, 1973.

6. DAVIES, C. T. M.; MBELWA, D.; CROCKFORD, G.; WEINER, J. S. “Exercise tolerance and body composition of male and female Africans aged 18-30 years." Human Biol., 45: 31-40, 1973.

7. FAULKNER, J. A.; ROBERTS, D. E.; ELK, R. L.; CONWAY, J. “Cardiovascular responses to submaximum and maximum effort cycling and running." J.Appl.Physiol., 30: 457-461, 1971.

8. FORBES, G. B.; GALLUP, J.; HURSH, J. B. "Estimation of total body fat from potassium-40 content." Sci., 133: 101-102, 1961.

9. FORBES, G. B.; SCHULTZ, F.; CAFARELLI, C.; AMIRHAKIMI, G. H. "Effects of body size on potassium-40 measurement in the whole body counter (tilt-chair technique)." HIth.Physics, 15: 435-442, 1968.

10. HERMANSEN, L.; ANDERSEN, K. L. "Aerobic work capacity in young Norwegian men and women." J.Appl.Physiol., 20: 425-431, 1965.

11. HERMANSEN, L.; EKBLOM, B.; SALTIN, B. "Cardiac output during submaximal and maximal treadmill and bicycle exercise." J.Appl.Physiol., 29: 82-86, 1970.

12. KATCH, V. L.; MICHAEL, E. D. "The relationship between various segmental leg measurements, leg strength and relative endurance performance of college females." Human Biol., 45: 371-383, 1973.

13. MACNAB, R. B. J.; CONGER, P. R.; TAYLOR, P. S. "Differences in maximal and submaximal work capacity in men and women." J.Appl.Physiol., 27: 644-648; 1969.

14. MAHADEVA, K.; PASSMORE, R.; WOOLF, B. "Individual variations in the metabolic cost of standardized exercises: the effects of food, age, sex, and race." J.Physiol. (London), 121: 225-231, 1953.

15. MAKSUD, M. G.; WILEY, R. L.; HAMILTON, L. H.; LOCKHART, B. "Maximal VO ${ }_{2}$, ventilation, and heart rate of Olympic speed skating candidates." J.Appl.Physiol., 29: 186-190, 1970.

16. MARDELL, M.; SYMMONS, C.; ZILVA, J. F. "A comparison of the effect of oral contraceptives, pregnancy and sex on iron metabolism." J. Clin. Endocrin.Metab., 29: 1489-1495, 1969.

17. MAYHEW, J. L. "A reliable, versatile system for assessing oxygen intake." Brit.J. Sports Med., 7: 360-362, 1973.

18. METHENY, E.; BROUCHA, L.; JOHNSON, R. E.; FORBES, W. H. “Some physiological responses of women and men to moderate and strenuous exercise: a comparative study." Am.J.Physiol., 137: 318-326, 1942. 
19. MIYAMURA, M.; HONDA, Y. "Oxygen intake and cardiac output during maximal treadmill and bicycle exercise." J.Appl.Physiol., 32: 185-188, 1972.

20. MOORE, F. D.; OLESEN, K. H.; McMURREY, J. D.; PARKER, H. V.; BALL, M. R.; BOYDEN, C. M. The body cell mass and its supporting environment. Philadelphia: W. B. Saunders, 1963.

21. NAGLE, F. J. "Physiological assessment of maximal performance," cited in Wilmore J. H. (ed.), Exercise and Sports Sciences Review. Philadelphia: W. B. Saunders, 1963.

22. SECHER, N. H.; RUBERG-LARSEN, N,; BINKHORTS, R. A.; BLONDE-PETERSON, F. “Maximal oxygen uptake during arm cranking and combined arm plus leg exercise." J.Appl.Physiol., 36: 515-518, 1974.

23. TWARDOCK, A. R.; LOHMAN, T. G.; SMITH, G. S.; BREIDENSTEIN, B. C. “The Illinois animal science counter: performance characteristics and animal radioactivity measurement procedures." J.Animal Sci., 25: 1209-1217, 1966.

24. VERLOOP, M. C.; BLOKHIUS, E. W. M.; BOS, C. C. “Causes of the differences in haemoglobin and serum-iron between men and women." Acta Haemat., 21: 199-205, 1959.

25. WILMORE, J. H.; BEHNKE, A. R. "An anthropometric estimation of body density and lean body weight in young men." J.Appl.Physiol., 27: 25-31, 1969.

26. WILMORE, J. H.; BEHNKE, A. R. "An anthropometric estimation of body density and lean body weight in young women." Am.J.Clin.Nutr., 23: 267-274, 1970. 